\title{
Güvenlik Kuvvetleri Personeline Yapılan Periyodik Sağlık Muayenelerinin Verimliliğinin Değerlendirilmesi
}

\section{Evaluating The Productivity of Periodic Medical Examinations Made for The Security Forces Personnel}

\author{
${ }^{1}$ Soykan ŞAHIN \\ ${ }^{1}$ Milli Savunma Bakanlığı, Çanakkale Boğaz Komutanlığı, Çanakkale, Türkiye
}

Soykan Şahin: https://orcid.org/0000-0001-9838-1152

\section{ÖZ}

Amaç: Periyodik sağlık muayeneleri personeli sağlıklı kılmak, erken tanı, tedavi ve rehabilitasyonu sağlayarak iş gücü kaybını engellemek ve verimliliği arttırmak amacıyla yapılır. Bu çalışmada güvenlik kuvvetleri personeline yönelik yapılan periyodik sağlık muayenelerinin verimliliğinin değerlendirilmesi amaçlanmıştır.

Materyal ve Metot: Tanımlayıcı tipte tasarlanan bu çalışmaya engelli raporu vermeye yetkili sağlık kurulu muayenesi yapılan yedi adet ikinci basamak kamu hastanesine başvuran 1209 kişi katılmıştır. Hasta bilgi formuyla önceden sağlık durumları belli olan hastalara muayene sonucunda yeni bir hastalık tanısı koyulup koyulmadığ saptanmıştır. Verimlilik ise katılımcıların bilinen bir hastalığı olsun ya da olmasın kendisine konulan yeni tan üzerinden oranlama analizi kullanılarak hesaplanmıştır.

Bulgular: Katılımcıların $461(\% 22,7)$ 'ine en çok göz hastalıklarıyla ilgili tanılar, $321(\% 15,8)$ 'ine kilo fazlalığı ve $284(\% 14)$ 'üne hiperlipidemi tanısı koyulurken 449 (\% $22,1)$ katılımcı tamamen sağlıklı bulunmuştur. Periyodik sağlık muayenelerinin verimliliği \%62,3 olarak saptanmıştir.

Sonuç: Çalışmamızda periyodik sağlık muayenesi verimliliği \%62,3'lük oranla orta düzeyde verimli olarak değerlendirilmiştir. Güvenlik kuvvetleri personelinin zaten sağl1klı kişilerden oluştuğu ve görev yapma şartlarından bir tanesinin de sağlıklı kalmak olduğu göz önüne alınd1ğında bu değer beklenen bir değerdir.

Anahtar Kelimeler: Güvenlik kuvvetleri, periyodik sağlık muayenesi, verimlilik

\begin{abstract}
Objective: Periodic health examinations are carried out in order to make the personnel healthy, to provide early diagnosis, treatment and rehabilitation, to prevent loss of workforce and to increase efficiency.In this study, it was aimed to evaluate the productivity of the periodic health examinations made for the security forces personnel.
\end{abstract}

Materials and Methods: This descriptive study included 1209 people who were admitted to the seven secondary healthcare public hospital to give a disability report. With the patient information form, it was determined whether a new disease was diagnosed as a result of the examination of the patients whose health status was previously determined.Efficiency was calculated using proportional analysis based on the new diagnosis made, whether the participants had a known disease or not.

Results: When the diagnoses of the participants were assessed $461(22.7 \%)$ of the participants were diagnosed with eye diseases, $321(15.8 \%)$ were overweight and 284 $(14.0 \%)$ were diagnosed with hyperlipidemia while 449 (22.1\%) participants were found healthy. The efficiency of periodic health examinations was determined to be $62.3 \%$. Conclusions: In our study, periodic health examination efficiency was evaluated as moderately efficient with a rate of $62.3 \%$. This value is an expected value considering that the security forces' personnel are already healthy people and one of the conditions of duty is to stay healthy. Keywords: Security forces, periodic health examination, efficiency
Sorumlu Yazar / Corresponding Author:

Soykan Şahin

Çanakkale Boğaz Komutanlığı, Merkez/Çanakkale

Tel: 90 - 5065097824

E-mail: soykansahindr@gmail.com
Yayın Bilgisi / Article Info:

Gönderi Tarihi/ Received: 24/11/2019

Kabul Tarihi/ Accepted: 25/06/2020

Online Yayın Tarihi/ Published: 30/09/2020 


\section{GÍRIŞ}

Sağlık hizmetlerinde en önemli nokta, kişilerin sağlıklarının korunmasını sağlamaktır ve önemli özelliklerinden biri de bu hizmetin başka hizmetle ikame edilememesidir. Örneğin yüksek maliyetli kalp kapakçı̆̆ı ameliyatının yerine daha düşük maliyetli olan çürük dişlerin tedavisi yapılamamaktadır. ${ }^{1}$

Koruyucu sağlık hizmetleri, hastalıklardan korunmanın yanı sıra erken tanı ve erken tedavi (ikincil koruma) ile hastalığın nüks ve komplikasyonlarından korumayı (üçüncül koruma) kapsamaktadır. ${ }^{2}$ İkincil korumayla uyumlu periyodik sağlı muayeneleriyle (PSM), işyerindeki nedenlerden ortaya çıkabilecek sağlık sorunlarının erken teşhisi yanında, ilerleyen yaşla birlikte kişilerde ortaya çıkabilen hastalıkların da (hipertansiyon, diabetes mellitus, kalp ve damar hastalıkları gibi) erken tanısı sağlanabilmektedir., ${ }^{3,4}$ PSM'lerinde günümüzün hastalıkları olan obezite, diyabet ve depresif bozukluk gibi rahatsızlıkların güvenlik kuvvetleri personeli arasında arttığını gösteren çalışmalar vardır., ${ }^{5,6}$ Amerika'da yapılan bir derleme, güvenlik kuvvetleri personelinde kardiyovasküler risk artışlarının giderek daha belirgin olduğunu göstermiştir. ${ }^{7}$ Fransa'da erkek güvenlik kuvvetleri personelinde yürütülmüş bir başka çalışmada katılımcıların \%9'nda metabolik sendromu tanımlayan beş kriterden en az üçünün bulunduğu bildirilmiştir. $^{8}$

İş sağlığı hizmetlerinin amacı çalışanları sağlıklı tutarak mevcut hallerinin devamını sağlamak, iş koşullarından kaynaklanabilecek zararlardan korumak, kişiyi psikolojik ve fizyolojik olarak uygun işe yerleştirmektir. ${ }^{3,4,9} \operatorname{Han}^{10}$, periyodik olarak yapılacak iyi bir sorgulama, fizik muayene ve laboratuar testleriyle sağlıktaki bir bozulmanın erken evrede tanımlanabileceğini vurgulamıştır. PSM ile ilgili yapılan bazı sistematik derlemelerde, bu gibi koruyucu sağlık hizmetlerinin yapılmasının hastaların kaygı seviyelerini düşürdüğü, maliyetlere, mortalite ve morbiditeye orta derecede, hastaneye yatışlara ise yüksek derecede olumlu katkılar sağladığı gösterilmiştir. ${ }^{11,12}$ Güvenlik kuvvetleri personeline yapılan bu muayenelerde kişiye öncelikle; akciğer grafisi, kan sayımı, sedimentasyon, rutin biyokimya, idrar tahlili, EKG, gaitada gizli kan, karın ultrasonografisi, erkekler için PSA, kadınlar için PAP smear, mamografi (yoksa meme ultrasonografisi) tetkikleri yapılmaktadır.

PSM'de amaç personeli sağlıklı kılmak, erken tanı, tedavi, rehabilitasyonu sağlayarak iş gücü kaybından korumak ve verimliliği arttırmaktadır. ${ }^{13}$ Muayeneler esnasında istenen tetkikler ile sağlık çalışanlarına getirdiği ilave yükler, hastanelerin iş yükünü ve sağlığa yapılan harcamaları arttırmaktadır. Bu nedenle hizmetlerin verimlilik düzeylerinin bilinmesi önem taşımaktadır. Zira kamu kaynaklarının ne kadar etkili kullandıklarının ve verimliliklerinin bilinmesi, kaynakların daha iyi yönetilmesine katkı sağlayabilecektir. $^{14}$

Sağlık sisteminde yer alan kaynak ve çıktılarla ilgili ilişkileri tanımlamak oldukça zordur. Bu çıktılardan biri olan verimlilik, ekonomik yönüyle para değil toplumsal yarar olarak tanımlanmaktadır. ${ }^{2}$ Verimlilik analizlerinde kullanılacak göstergeler sorunları ortaya koymalı, hangi alanlarda geliştirilmeye gidilmesi gerektiğini göstermelidir. ${ }^{15}$ Verimlilik hesaplamasında kullanılan bazı etkililik ölçütleri; önlenen ölüm sayısı, hastalıktan korunan kişi sayısı ve tanı koyulan kişi sayısıdır. Verimlilik ölçümlerinde çok farklı yöntemler kullanılsa da en çok kullanılanı oran analizidir. $^{16}$

$\mathrm{Bu}$ çalışmada, ikinci basamak sağlık teşkillerince yürütülen periyodik muayene işlemlerinin verimliliğinin değerlendirilmesi amaçlanmıştır.

\section{MATERYAL VE METOT}

Araştırma tanımlayıcı tipte planlanmıştır ve Gülhane Askeri Tıp Akademisi Etik Kurul Başkanlığı'ndan etik kurul izni alınmıştır (Tarih: 12/11/2013, karar no: 50687469-1491-2356-13/1648.4-2517). Çalışmamızın örneklemini 1 Ocak-31 Mart 2014 tarihleri arasında, sağlık kurulu raporu vermeye yetkili yedi adet ikinci basamak kamu hastanesine periyodik sağlık muayenesi için başvuran ve çalışmaya katılmaya yazılı onam veren 1209 güvenlik kuvvetleri personeli oluşturmuştur. Çalışma yeri olarak Türkiye'de güvenlik kuvvetleri personelinin daha çok periyodik sağlık muayenesini yaptırmak için başvurduğu 3'ü Ankara'da, birer tanesi de Diyarbakır, Erzurum, Balıkesir ve İstanbul'da olan toplam 7 hastane seçilmiştir. Katılımcılardan sadece ikisi kadın personel olduğu için araştırmamızda cinsiyetin etkisi değerlendirilmemiş, cinsiyete ilişkin analizler yapılmamıştır.

Her hastanın sosyodemografik özelliklerinin ve mevcut sağlık durumunun (hastaya ait kimlik bilgileri ile daha önce veya şu anda sahip olduğu hastalıklar, geçirdiği ameliyatlar, kullandığı ilaçlar gibi) tespiti için araştırmacı tarafından hasta bilgi formu hazırlanmıştır. Hasta bilgi formu hastaya sağlık kurulunda kayıt işlemi sırasında araştırmacı tarafından uygulanmıştır.

Soru formlarının toplanması işlemine müteakip bir 
ay içerisinde hastane sağlık otomasyon sistemi üzerinden hastaların muayene sonucunda kliniklerden aldığı tanılar ve kurul kararı bilgileri alınmıştır. Böylelikle önceden sağlık durumu belli olan hastalara periyodik muayene sonucunda yeni bir hastalık tanısı koyulup koyulmadığı saptanmıştır. Kişilerin aldıkları tanılar çok çeşitlilik arz ettiğinden ve aynı tanı birkaç değişik isimle işlendiğinden tanılar araştırmac1 tarafından sistem, organ ve klinik benzerlik göz önüne alınarak gruplandırılmıştır.

Araştırmamız bir maliyet etkililik analizi olmadığ için maliyet hesaplarına girilmemiş verimlilik, katılımcıların bilinen bir hastalığ 1 olsun ya da olmasın kendisine konulan yeni tanı üzerinden oranlama analizi kullanılarak hesaplanmıştır.

Toplanan veriler bilgisayar ortamına aktarıldıktan sonra SPSS 15.0 paket programı ile analizleri yapılmıştır. Tanımlayıcı istatistik olarak sayı, yüzde, ortalama, standart sapma, en küçük ve en büyük değerler, kesikli verilerin karşılaştırılmasında Ki Kare testi kullanılmıştır. İstatistiksel anlamlılık değeri olarak $\mathrm{p}<0,05$ kabul edilmiştir.

\section{BULGULAR}

Katılımcıların yaş ortalaması $35,9 \pm 7,3$ yıl (en küçük=22, en büyük=55) olarak bulunmuştur. Katılımcıların periyodik muayene işlemlerini gerçekleştirdikleri yedi adet ikinci basamak kamu hastanesine göre dağılımları Tablo 1'de gösterilmiştir.

Çalışma kapsamındaki kişilerin yaş gruplarına göre dağılımları incelendiğinde $1054(\% 87,2)$ 'ünün 45 yaş altında, $155(\% 12,8)$ 'inin ise 45 yaş ve üstünde oldukları saptanmıştır.

Katılımcılara periyodik muayene sonucu verilen kararlar incelendiğinde ilk üç sırayı 461 (\%22,7) kişiyle göz hastalıkları, 321 (\%15,8) kişiyle kilo fazlalığı ve $284(\% 14,0)$ kişiyle hiperlipidemi oluştururken $449(\% 22,1)$ kişi tam sağlam kararı almıştır. Verilen kararların hastalık türlerine göre gruplandırılmış dağılımı Tablo 2'de gösterilmiştir.

Katılımcilara muayene sonunda konulan tanıların yaş gruplarına göre dağılımları Tablo 3 'te gösterilmiştir. Göz hastalıklarına sahip olanların 374 (\% 81,1)'ü, hiperlipidemisi olanların 220 (\%77,5)'si ve kilo fazlalığı olanların $263(\% 81,9)$ 'ü 45 yaş altındadir.

Katılımcılara periyodik muayene işlemleri sonucunda verilen kilo fazlalığı kararının yaş gruplarına göre karşılaştırılması sonucunda, 45 yaş altı ile 45 yaş ve üstü yaşlar arasında kilo fazlalığı sıklığı yönünden istatistiksel olarak anlamlı fark bulunmamışken $(p=0,9)$; hiperlipidemi kararının yaş gruplarına göre karşılaştırılması sonucunda yaş grupları arasında hiperlipidemi sıklığı yönünden anlamlı fark bulunmuştur $(\mathrm{p}=0,03)$.

Periyodik sağlık muayenelerinde daha önceden bilinen bir hastalığı olup da ilave bir yeni tanı alanlar $131(\% 77,1)$ kişi olarak bulunmuştur. Tablo 4’ten de anlaşılacağı gibi mevcut hastalığı olan $39(\% 22,9)$ kişi mevcut rahatsızlıklarının dışında yeni bir tanı almamıştır. Mevcut hastalığı olsun ya da olmasın periyodik muayeneler 1209 kişinin 753'üne (\%62,3) yeni bir tanı koymuştur. Yeni bir tanı koyması üzerinden yapılan verimlilik hesabıyla periyodik muayenelerin verimliliği \%62,3 olarak bulunmuştur.

\section{TARTIŞMA VE SONUC}

Çalışmada periyodik muayene sonucunda verilen kararlar belirlenmiş ve personele yeni bir tanı koyulması esas alınarak periyodik muayenelerin verimliliği hesaplanmıştır. Çalışmanın periyodik sağlık muayeneleriyle ilgili mevzuat kapsamında ülkemizdeki kurum ve kuruluşların bu konuda yürüttükleri faaliyetleri gözden geçirerek ve bu muayenelerin verimliliğini artırmaya yönelik öneriler geliştirmelerine önemli katkılar sağlayacağı değerlendirilmektedir.

Çalışmamız tanımlayıcı tipte bir olduğundan sonuçların genellenebilir özelliği zayıftır. Hasta bilgi formuna verilen cevapların katılımcılara bağlı olması, hastane bilgi sistemi üzerinden kişilerin mevcut sağlık durumlarıyla ilgili bilgilere ulaşılamaması nedeniyle biasa (taraf tutma) neden olmuş olabilir. Örneğin miyopisi olan biri bunu kusur olarak görmeyip beyan etmediği için "kendisine yeni bir tanı koyulmuş" kategorisinde analiz yapılmış olabilir. Bazı katılımcılar hastalığı olduğunu beyan etmesine rağmen sağlam tanısı almışlardır. Bu durumun hastanın mevcut sağlık durumunu yanlış beyan etmesine, hasta bilgi formunda beyan ettiği hastalığını muayene sırasında doktoruna söylememesine bağlı olduğu değerlendirilmektedir.

Katılımciların neredeyse hemen tamamının erkeklerden oluşması ve araştırma kapsamındaki katılımcılar arasında iki tane kadın personel olmasından dolayı cinsiyetin etkisine yönelik analizler yapılmamıştır.

Tanılar sıklık sırasına göre incelendiğinde, göz hastalıklarının $461(\% 22,7)$, hastalık veya arızası olmayan tam sağlamların 449 (\%22,1), kilo fazlalığının $321(\% 15,8)$ ve hiperlipideminin $284(\% 14,0)$ kişiyle en sık verilen ilk dört karar olduğu saptanmıştır. 2009 yılında Al-dahi ve arkadaşlarının ${ }^{17} 10229$ Suudi Arabistan Silahlı Kuvvetleri personelinde yaptıkları çalışmadaki katılımcılarda hiperlipidemi sıklığı \%29,3 bulunmuştur. 
Hem 45 yaş altı hem de 45 yaş üzeri kişilerde en sık görülen hastalıklar göz hastalıkları, kilo fazlalığı ve hiperlipidemidir. Bunlardan sadece hiperlipidemi sıklığında yaş grupları arasında istatistiksel olarak bir fark tespit edilmiştir. Bu durumun yaşla birlikte kronik hastalıkların görülme sıklığındaki artışa bağlı olduğu değerlendirilmektedir. Niebuhr ve arkadaşlarının $^{18} 2005$ yılında ABD ordusundaki 8858 erkek uzman erbaş/er üzerinde yaptıkları çalışmada kilo fazlalığı sıklığı \%9,3 bulunmuştur. Sundin ve arkadaşları $^{19}$ ise 2007 yılında İngiliz Ordusunda 2073 erkek personel üzerinde yaptıkları çalışmada 25 yaşından küçüklerde \%6,2, 25-34 yaş aralığında \% $15,0,35$ yaş ve üzerinde $\% 24,5$ sıklığıyla kilo fazlalığı olduğunu tespit etmişlerdir. Bu iki ülkeyle karşılaştırıldığında çalışmamızda kilo fazlalığının \%15,8 ile daha sık olduğu görülmektedir.

Periyodik muayenelerin temel amac1, personelin genel sağlık taramasının yapılarak var olan rahatsızlıklarının tanısının konulması ve doğabilecek hastalıkların erkenden farkına varılarak önlenmesi amacıyla müdahalelerde (sağlık eğitimi, tedavi başlanması gibi) bulunulmasıdır. Daha önceden bilinen bir hastalığ koyması üzerinden yapılan verimlilik hesabında örneklemimiz için gerçekleşen verimlilik \%62,3 bulunmuştur. Bu oran orta düzeyde verimli olarak kabul edilebilir. Güvenlik kuvvetleri personelinin zaten sağlıklı kişilerden oluştuğu ve görev yapma şartlarından bir tanesinin de sağlıklı kalmak olduğu göz önüne alındığında bu değer beklenen bir değerdir.

Mevcut periyodik muayene sisteminin verimliliği üzerinden bilimsel bir değerlendirmesi yapılmıştır. Söz konusu muayenelerin getirdiği iş yükünün tespit edilerek azaltılmasına yönelik muayene modellerinin ve ekonomik değerlendirme tekniklerinin de kullanıldığı ileri düzey çalışmalara ihtiyaç olduğu değerlendirilmektedir.

Etik Komite Onayı: Çalışmamız Gülhane Askeri Tip Akademisi Etik Kurulu tarafindan 12.11.2013'de (karar no: 50687469-1491-235613/1648.4-2517) onayland1.

Çıkar Çatışması: Yazarlar çıkar çatışması bildirmemişlerdir.

Yazar Katkıları: Fikir - SŞ; Denetleme-SŞ; Malzemeler - SŞ; Veri toplanması ve/veya işlemesi- SŞ; Analiz ve/veya yorum -SŞ; Yazıyı yazan - SŞ.

Hakem değerlendirmesi: Dış bağımsı.
1. Saltık A. Sağlık Ekonomisinde Yeni Kavramlar. Toplum ve Hekim. 1995;10(68):38-44.

2. Türk Tabipler Birliği. Prof.Dr. Nusret Fişek'in Kitaplaşmamış Yazıları-1, Sağlık Yönetimi, 1997. https://www.ttb.org.tr/n fisek/ kitap_1/10.html. Erişim tarihi 22 Haziran 2020.

3. Çalışma ve Sosyal Güvenlik Bakanlığı. Meslek Hastalıkları ve İş ile İlgili Hastalıklar Tanı Rehberi, 2011. https://www.ailevecalisma.gov.tr/ media/1340/meslekhastaliklari.pdf. Erişim tarihi 22 Haziran 2020.

4. Bilir N, Yıldız AN. İş Sağlığı ve Güvenliği, Halk Sağlığı Temel Bilgiler Cilt II, Ankara, Hacettepe Üniversitesi Yayınlar1; 2012.

5. McLaughlin R, Wittert G. The obesity epidemic: implications for recruitment and retention of defense force personnel. Obesity Rewiews. 2009; 10 (6):693-699.

6. Wilson AL, Messer SC, Hoge CW. U.S. Military mental health care utilization and attrition prior to the wars in Iraq and Afghanistan. Social Psychiatry and Psychiatric Epidemiology. 2009;44:473-481.

7. McGraw LK, Turner BS, Stotts NA, Dracup KA. A review of cardiovascular risk factors in US military personnel. Journal of Cardiovascular Nursing. 2008;23:338-344.

8. Bauduceau BBF, Bordier L, Burnat P, ve ark. Epidemiology of the metabolic syndrome in 2045 French military personel (EPIMIL study). Diabetes and Metabolism. 2005;31:353-359.

9. Topuzoğlu İ, Orhun H. Türk Tabipler Birliği, İş Hekimliği Ders Notları. 3. Basım, Ankara: Maya Matbaacilık; 1993.

10. Han PK. Historical changes in the objectives of the periodic health examination. Ann Intern Med. 1997;127:910-917.

11. Fletcher RH. Periodic health examination increases delivery of some clinical preventive services and reduces patient worry. ACP J Club. 2007;147(1):6.

12. Boulware LE. Value of the periodic health evaluation. Agency for healthcare research and quality, U.S. Department of Health and Human Services, Rockville; 2006.

13. Öniz H. Sağlık ve Verimlilik. TMMOB Makina Mühendisleri Odası. http://www.mmo.org.tr/ resimler/dosya_ekler/bfe3596365caaf5_ek.pdf. Erişim tarihi 3 Ocak 2014.

14. Çelik Y. Sağlik Ekonomisi, Ankara, Siyasal Kitabevi; 2011.

\section{KAYNAKLAR}


15. Akal Z. İşletmelerde performans ölçüm ve denetimi, Ankara, MPM Yayınları; 2002.

16. Şahin İ. Sağlık Bakanlığı genel hastaneleri ve Sağlık Bakanlığına devredilen SSK Genel Hastanelerinin teknik verimliliklerinin karşılaştırılmalı analizi. Hacettepe Sağlık İdaresi Dergisi. 2008;11(1):1-48.

17. Al-Dahi S, Al-Khashan H, Al Madeer MA, ve ark. Assesment of framingham cardiovasculer disease risk among militaries in the kingdom of Saudi Arabia. Military Medicine. 2013;178:299305.

18. Niebuhr DW, Scott CT, Li Y, Bedno SA, Han W, Powers T. Precession fitness and body composition as predictors of attrition in US army recruits. Military Medicine. 2009;174:695-701.

19. Fear NT, Sundin J, Rona R. Obesity in the United Kingdom armed forces: Prevalance based on measured and self-reported data. Military Medicine. 2011;176:44-49. 
Tablo 1. Katılımcıların araştırma yapılan hastanelere göre dağılımları.

\begin{tabular}{|l|c|c|}
\hline Çalışma Kapsamındaki Hastaneler & Sayı (n) & Yüzde (\%) \\
\hline 1. Kamu Hastanesi (Ankara) & 261 & 21,6 \\
\hline 2. Kamu Hastanesi (Ankara) & 217 & 17,9 \\
\hline 3. Kamu Hastanesi (Ankara) & 197 & 16,3 \\
\hline 4. Kamu Hastanesi (Balıkesir) & 147 & 12,1 \\
\hline 5. Kamu Hastanesi İstanbul) & 95 & 7,9 \\
\hline 6. Kamu Hastanesi (Diyarbakır) & 131 & 10,8 \\
\hline 7. Kamu Hastanesi (Erzurum) & 161 & 13,3 \\
\hline Toplam & $\mathbf{1 2 0 9}$ & $\mathbf{1 0 0 , 0}$ \\
\hline
\end{tabular}


Tablo 2. Çalışmaya dahil olan personele verilen kararların dağılımları

\begin{tabular}{|l|c|c|}
\hline Kararlar & Sayı (n) & Yüzde (\%) \\
\hline Göz hastalıkları (Refraksiyon Kusurları, lens ve korneayla ilgili patolojiler) * & 461 & 22,7 \\
\hline Tam Sağlam & 449 & 22,1 \\
\hline Kilo Fazlalığı & 321 & 15,8 \\
\hline Hiperlipidemi & 284 & 14,0 \\
\hline Karaciğer Fonksiyon Testlerinde Bozukluk & 108 & 5,3 \\
\hline Karaciğer Yağlanması & 59 & 2,9 \\
\hline Hiperglisemi, Hipoglisemi, Diyabet & 56 & 2,8 \\
\hline $\begin{array}{l}\text { Kalp ve Damar Hastalıkları (hipertansiyon, aterosklerotik kalp, dal blokları, vent- } \\
\text { rikül yetmezlikleri) * }\end{array}$ & 53 & 2,6 \\
\hline Anksiyete, Depresif Bozukluklar, Kişilik Bozuklukları & 45 & 2,2 \\
\hline Alt ve Üst Ekstremitenin Ortopedik Hastalıkları & 44 & 2,2 \\
\hline İşitme Kayıpları (iletim tipi, sensörinöral tip)* ve KBB Hastalıkları & 40 & 2,0 \\
\hline $\begin{array}{l}\text { Üriner Sistemin Hastalıkları (böbrek taşı, böbrek kisti, glomerüler hastalıklar, tek } \\
\text { böbrek) * }\end{array}$ & 25 & 1,2 \\
\hline Hepatitler (kronik viral hepatit, viral hepatit taşıyıılı̆̆ı) & 16 & 0,8 \\
\hline $\begin{array}{l}\text { Hematolojik Bozukluklar ve Maligniteler (anemi, polisitemi, trombositopeni, } \\
\text { talasemi taşıyıcılığı) * }\end{array}$ & 13 & 0,6 \\
\hline Safra Kesesi Hastalıkları (safra kesesi taşı, agenezisi) * & 11 & 0,5 \\
\hline Akciğer Hastalıkları (tüberküloz, amfizem, astım bronşiale) * & 8 & 0,4 \\
\hline $\begin{array}{l}\text { Tiroid Bezi Hastalıkları (hipotiroidizm, hipertirodizim, toksik olmayan multino- } \\
\text { düler guatr) * }\end{array}$ & $\mathbf{2 0 2 8}$ & $\mathbf{1 0 0 , 0}$ \\
\hline Reflü ve Özafajitler & 5 & 0,3 \\
\hline $\begin{array}{l}\text { Diğer (lipom, Cilt Hastalıkları, Overin Benign Neoplazmları, appendiks hastalık- } \\
\text { ları, dalak kisti vb.) * }\end{array}$ & 23 & 0,2 \\
\hline Toplam & 7,1 \\
\hline
\end{tabular}

*Hastalık ve rahatsızlıklar araştırmacı tarafından sistem, organ ve klinik benzerlik dikkate alınarak gruplandırılmıştır. 
Tablo 3. Sık gör ülen hastalıkların katılımcıların yaş gruplarına göre dağılımı.

\begin{tabular}{|l|c|c|}
\hline Tanılar & $\begin{array}{c}\text { 45 Yaş Altı } \\
\text { n (\%) }\end{array}$ & $\begin{array}{c}\text { 45 Yaş ve } \\
\text { Üstü }\end{array}$ \\
\hline Göz hastalıkları (Refraksiyon Kusurları, lens ve korneayla ilgili patolojiler) * & $374(81,1)$ & $87(18,9)$ \\
\hline Tam Sağlam & $424(94,4)$ & $25(5,6)$ \\
\hline Kilo Fazlalığı & $263(81,9)$ & $58(18,1)$ \\
\hline Hiperlipidemi & $220(77,5)$ & $65(22,5)$ \\
\hline Karaciğer Fonksiyon Testlerinde Bozukluk & $96(88,9)$ & $12(11,1)$ \\
\hline Alt ve Üst Ekstremitenin Ortopedik Hastalıkları & $40(90,9)$ & $4(9,1)$ \\
\hline Karaciğer Yağlanması & $39(66,1)$ & $20(33,9)$ \\
\hline Hiperglisemi, Hipoglisemi, Diyabet & $39(69,6)$ & $17(30,4)$ \\
\hline Anksiyete, Depresif Bozukluklar, Kişilik Bozuklukları & $38(84,4)$ & $7(15,6)$ \\
\hline Kalp ve Damar Hastalıkları (hipertansiyon, dal blokları, aterosklerotik kalp, & $33(62,3)$ & $20(37,7)$ \\
\hline İitme Kayıpları (iletim tipi, sensörinöral tip)* ve KBB Hastalıkları & $25(62,5)$ & $15(37,5)$ \\
\hline Üriner Sistemin Hastalıkları (böbrek taşı, böbrek kisti, glomerüler hastalıklar, & $14(56,0)$ & $11(44,0)$ \\
\hline Hepatitler (kronik viral hepatit, viral hepatit taşıyıcılı̆̆ı)* & $12(75,0)$ & $4(25,0)$ \\
\hline Hematolojik Bozukluklar ve Maligniteler (anemi, polisitemi, trombositopeni, & $11(84,6)$ & $2(15,4)$ \\
\hline Safra Kesesi Hastalıkları (safra kesesi taşı, agenezisi)* & $5(45,5)$ & $6(54,5)$ \\
\hline Reflü ve Özafajitler & $5(100,0)$ & - \\
\hline Tiroid Bezi Hastalıkları (hipotiroidizm, toksik olmayan multinodüler guatr & $4(57,1)$ & $3(42,9)$ \\
\hline Akciğer Hastalıkları (tüberküloz, amfizem, astım bronşiale) * & $3(37,5)$ & $5(62,5)$ \\
\hline Diğer (lipom, Cilt Hastalıkları, OverinBenignNeoplazmları, appendiks hasta- & $17(73,9)$ & $6(26,1)$ \\
\hline Toplam & $\mathbf{1 6 6 2 ( 8 2 , 0 )}$ & $\mathbf{3 6 6}(\mathbf{1 8 , 0})$ \\
\hline
\end{tabular}

*Hastalık ve rahatsızlıklar araştırmacı tarafından sistem, organ ve klinik benzerlik dikkate alınarak gruplandırılmıştır. †Satır Yüzdesi. 
Tablo 4. Periyodik muayene sonucunda alınan tanılarla bilinen hastalık durumlar1.

\begin{tabular}{|l|c|c|c|}
\hline & $\begin{array}{c}\text { Yeni tanı alanlar } \\
\mathbf{n}(\mathbf{\%}) *\end{array}$ & $\begin{array}{c}\text { Yeni tanı almayanlar } \\
\mathbf{n}(\%)\end{array}$ & Toplam \\
\hline Mevcut hastalığı olanlar & $131(77,1)$ & $39(22,9)$ & $170(100)$ \\
\hline Mevcut hastalığı olmayanlar & $622(59,9)$ & $417(40,1)$ & $1039(100)$ \\
\hline Toplam & $\mathbf{7 5 3 ( 6 2 , 3 )}$ & $\mathbf{4 5 6 ( 3 7 , 7 )}$ & $\mathbf{1 2 0 9}(\mathbf{1 0 0})$ \\
\hline
\end{tabular}

*Satır Yüzdesi. 